\title{
ISTRAŽIVANJE PROFILA TURISTA PREMA MOTIVIMA DOLASKA I LOJALNOSTI STILU ODMORA
}

\section{EXPLORING MOTIVES AND PROFILES OF THE TOURISTS AND THEIR LOYALTY TO THE STYLE OF HOLIDAY}

\begin{abstract}
SAŽETAK: Lojalnost stilu odmora nova je vrsta lojalnosti turista koja sve više zauzima pažnju u društvenim istraživanjima. Temeljna razlika u odnosu na ostale vrste lojalnosti kao što su lojalnost brendu ili lojalnost destinaciji leži u predmetu iskazivanja lojalnosti. Naime, turisti lojalni svom stilu odmora svoju lojalnost iskazuju prvenstveno svojim dobro poznatim načinima trošenja slobodnog vremena za vrijeme odmora, neovisno o destinaciji ili smještaju u kojem borave. Rad ima tri glavna cilja, prvi je izdvojiti motive dolaska turista na Opatijsku Rivijeru, drugi, izlučiti klastere prema motivacijskoj pripadnosti, i treći cilj je utvrditi njihovu uzročnu-posljedičnu vezu s namjerom preporuke stila odmora te namjerom ponovnog dolaska. U radu je korištena eksploratorna faktorska analiza (EFA) u cilju izlučivanja motivacijskih čimbenika, Two-step klaster analiza i ANOVA (Analiza varijance) za definiranje klastera, te $O L S$ regresijska analiza za utvrđivanje značajnosti prediktora lojalnosti stilu odmora. Rezultati istraživanja ukazuju da „turisti željni odmora, uzbuđenja i socijalne bliskosti“ imaju statistički značajniju namjeru ponovnog dolaska i namjeru preporuke stila odmora u odnosu na drugi klaster „turisti željni i odmora i socijalne distance“. Rezultati regresijske analize ukazuju da turisti koji su motivirani odmorom i relaksacijom, imaju namjeru ponovnog dolaska i namjeru preporuke svog stila odmora.
\end{abstract}

KLJUČNE RIJEČI: lojalnost stilu odmora, motivacijski čimbenici, Two-step klaster analiza

ABSTRACT: Loyalty to the style of a holiday as the new type of tourist's loyalty gradually is becoming a trending topic in social research. The main difference compared to other loyalty types such as brand loyalty or destination loyalty lies in the object to which loyalty is expressed. Namely, tourists loyal to their style of holiday, express loyalty toward their way of spending free time, regardless of destination or accommodation during their

Doc. dr. sc. Marina Laškarin Ažić, Fakultet za menadžment u turizmu i ugostiteljstvu, Primorska 42, p.p. 97, 51410 Opatija 
stay. This paper has three aims, first, to extract motivational reasons of respondents who had one or more overnight stays at Opatija Riviera, second, to reveal their meaningful clusters, and third, to determine the existence of a causal relationship between motivational background and loyalty intentions (to revisit and to recommend). To meet study objectives, the author has applied Exploratory Factor Analysis, Two-step cluster analysis, ANOVA, and OLS regression analysis. Results indicate that the first cluster "Tourists who seek for rest and relaxation, excitement, and social contacts" compared to the second cluster "Tourists who seek for rest and relaxation without social contact" have higher intentions to revisit and recommend.

KEY WORDS: Loyalty to the style of holiday, motives, Two-step cluster analysis

\section{UVOD}

Utvrđivanje naklonosti destinaciji i turističko ugostiteljskim poduzećima u istraživačkim krugovima predstavlja osnovni način mjerenja feedbacka turista o ispunjenosti njihovih očekivanja. S obzirom na to da zadovoljni turisti nisu nužno i turisti koji svoju lojalnost iskazuju ponovnim dolaskom, važno je utvrditi i druge načine iskazivanja lojalnosti. Naime, postoje dva temeljna načina izražavanja lojalnosti turista, to su lojalnost ponašanjem (stvarni dolasci), te lojalnost stavom (namjera ponovnog dolaska, namjera preporuke prijateljima i rodbini, osjećaj povezanosti i sl.). Iako lojalnost stavom, nema toliko vidljivu financijsku korist od turista koju je moguće izmjeriti kroz stvarne ponovljene dolaske, lojalnost stavom iznimno je važan način iskazivanja naklonosti, s obzirom na potencijal širenja pozitivnih dojmova među drugim potencijalnim turistima, ali i na mogućnost utvrđivanja psihološke povezanosti s turistima.

Lojalnost turista destinaciji ili nekom hotelskom brendu u znanstvenim krugovima percipiraju se kao dobro istražene teme. Osim navedenih temeljnih vrsta lojalnosti turista, lojalnost se sve više istražuje kroz druge prizme ili oblike izražavanja kao što su to horizontalna lojalnost ili vertikalna lojalnost (Almeida-Santana i Moreno-Gil, 2018). Predmeti istraživanja lojalnosti tako odmiču od iskazivanja lojalnosti prema jednom brendu, hotelu ili destinaciji u smjeru izražavanja lojalnosti, koje se smatraju nematerijalnim i usko povezanim sa samim doživljajem turista. Kao primjer može se istaknuti lojalnost određenim sportskim aktivnostima (golf, skijanje, jedrenje i sl.) ili lojalnost stilu odmora (McKercher, Denizci-Guillet, i Ng, 2012). Takav odmak u istraživanjima prvenstveno reflektira promjene koje se događaju na strani turističke potražnje. Turisti danas putuju češće, više puta godišnje (The Guardian, 2019), izuzevši 2020. godinu u kojoj se privremeno zaustavio takav trend. Međutim, s popuštanjem epidemioloških mjera očekuje se da će se turisti vratiti svojim omiljenim stilovima ponašanja i aktivnostima koje su privremeno zapostavili uslijed zabrane turističkih putovanja.

Mnoge atrakcije i destinacije ovise o segmentu koji se ponovno vraća i dijeli pozitivne dojmove među svojim prijateljima i rodbinom, pa tako i Opatijska rivijera. Stoga je ključno da destinacijski menadžeri otkriju ispunjenost njihovih očekivanja vezanih za primarni motiv dolaska kao i stil odmora. Osim toga, važno je razumjeti cjelokupni proces stvaranja pozitivnih dojmova kroz doživljaje u destinaciji kako bi se u konačnici bolje odredili ključni momenti za stvaranje nezaboravnog doživljaja. Istraživanja ukazuju da s 
porastom iskustva u putovanjima, turisti imaju jasniju sliku o načinu trošenja slobodnog vremena (McKercher, Denizci-Guillet, i Ng, 2012). Točnije, autori su otkrili da polovina od ukupnog broja istraživanih oblika putovanja, uključuje ponovljeni oblik aktivnosti ili doživljaja. Uvažavajući navedeno, kroz istraživački rad usmjerava se na individualne načine trošenja slobodnog vremena profilirajući turiste u segmente prema motivima dolaska. S obzirom na to da se do sada na području Hrvatske nije provodilo ovakvo istraživanje, korist se može podijeliti u dva temeljna pravca za 1) buduće istraživače lojalnosti nematerijalnih unutarnjih vrijednosti i 2) destinacijske menadžment organizacije i kompanije koje će imati bolji uvid u tzv. novi oblik lojalnosti i profile turista prema motivacijskim čimbenicima.

Svrha ovog rada je profilirati turiste kroz izlučene motivacijske čimbenike te odrediti njihovu namjeru ponovnog dolaska radi stila odmora i namjeru preporuke. Nadalje, u ovom istraživanju otkrit će se koja je od motivacijskih kategorija (push ili pull) ključna u utjecaju na lojalnost stilu odmora.

\section{MOTIVACIJSKA POZADINA TURISTA}

U turizmu, autori su istraživali različite motivacijske čimbenike povezujući ih s lojalnim stavovima, čime su se postupno razvijali složeniji modeli lojalnosti. Kao primjer toga su: sportski motivi, samopoštovanje, estetski, postignuće, znanje (Woo, Trail, Kwon, i Anderson, 2009), motivi za putovanje (potraga za novim, povezivanje, zabava u slobodno vrijeme (Wong i Tang, 2016); push motivi (relaksacija, obiteljsko okupljanje, sigurnost i zabava, novi doživljaji, odmor, uživanje u prirodi, širenje kulturnih horizonata); pull motivi (lokalna kuhinja, noćni život, pouzdano vrijeme, čistoća, mogućnosti shoppinga) i sl. (Anton, Camarero, i Laguna-Garcia, 2014; Yoon i Uysal, 2005). Prema autorima Yi, Fu, Jin i Okumus (2018) mjerenje motivacije kroz push i pull tipologiju predstavlja temeljni način utvrđivanja motiva dolaska turista. Pull motivacija uključuje sve eksterne - destinacijske atribute, koji utječu na poticanje želje za dolaskom turista kao što su sigurnost destinacije, atrakcije, lijepo vrijeme i sl.). S druge strane, push motivi turista izviru iz unutarnjih potreba kao što su bijeg od stvarnosti, avanturizam, socijalna interakcija i sl.

U cilju utvrđivanja povezanosti navedenih push i pull motiva s logičnim slijedom razmišljanja turista, autori Harril i Potts (2002) predlažu psihološki model motivacije kojim se objašnjava ponašanje turista u destinaciji kroz elemente: (1) potrebe i motivi, (2) ponašanje i aktivnosti, (3) ciljevi i zadovoljstvo, te (4) feedback. Navedeni elementi sekvencijalno se mogu objasniti putem sljedećeg primjera; turisti sa snažnom željom promjene mjesta prebivališta u cilju odmora i relaksacije i željom za druženjem (motivi), dolaze u destinaciju i provode svoj odmor u svom poznatom stilu, čime se kroz stvaranje novih prijateljstava i povezivanja ostvaruje njihova početni motiv dolaska (ispunjenje cilja i zadovoljstvo). Kao rezultat tog (ne)ispunjenja, turisti dijele svoja iskustva s drugima te izražavaju svoju namjeru za ponovnim dolaskom (feedback).

U cilju izdvajanja homogenih sub-grupa, istraživači segmentiraju turiste u manje homogene grupe kroz dva temeljna pristupa: 1) a priori pri čemu se prvo definira baza za segmentiranje, nakon čega se koristi pripadajuća metoda profiliranja kako bi se odvojili 
segmenti, s druge strane 2) posteriori pristup pretpostavlja da postoje ograničene informacije o segmentima, te se segmenti definiraju na temelju primjene statističkih metoda (Dolnicar, 2004).

U ovom radu pri istraživanju motiva turista koji dolaze na Opatijsku rivijeru ponuđeni su push i pull motivi te se koristio posteriori pristup kako bi se izdvojili ključni segmenti.

\section{STIL ODMORA KAO ZAJEDNIČKI NAZIVNIK PREFERIRANIH AKTIVNOSTI I DOŽIVLJAJA}

U turističkom kontekstu potreba za tjelesnim odmorom ili oporavkom (spavati, jesti, piti) smanjila se u korist potrebe za „obnovom duševnog“ i to kroz aktivnosti, doživljaje koji u svakodnevnici turista nisu mogući. Žudnja za njihovim ispunjenjem oblikuje se u motive koji proizlaze iz vjerovanja i identiteta osobe, čineći tako temeljni pokretač njihova ponašanja. S obzirom na to da se stil odmora također promatra kao svojevrsni pokretač (ponovnog) dolaska, potrebno je izdvojiti neke osnovne razlike u značenju navedenih pojmova. Naime, turist $\mathrm{X}$ i turist $\mathrm{Y}$ mogu imati isti motiv dolaska u destinaciju, dok način trošenja slobodnog vremena ne mora biti isti. Tako primjerice, motiv dolaska može biti zajednički (odmor i relaksacija), međutim aktivnosti koje će ta dva turista provoditi u destinaciji ne mora odražavati njihove zajedničke motive. Stil odmora uključuje puno širi kontekst ponašanja turista (slika 1), čime se reflektira iskustvo turista, spremnost izdvajanja novčanih sredstava i vremena u određenim aktivnostima i sl. (Laškarin Ažić i Suštar, 2021).

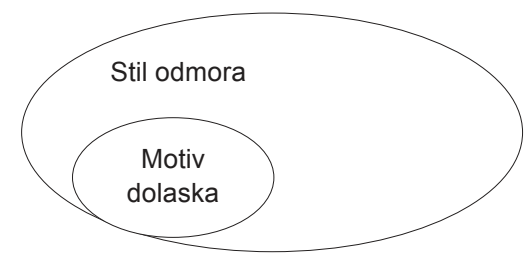

Slika 1. Odnos stila odmora i motiva dolaska

Izvor: izrada autora

U turističkoj literaturi, među autorima postoji određeni konsenzus oko pozitivne veze između kvalitete doživljaja i namjere njihova ponovnog dolaska (Suhartanto, Brien, Primiana, Wibisono i Nyoman, 2019). Doživljaji kao rezultat aktivnosti u destinaciji postaju temeljni razlog ponovnog dolaska u destinaciju (Chang, Backman i Huang, 2014). Pri istraživanju doživljaja i aktivnosti u destinaciji i povezanosti s lojalnim namjerama većina autora usmjerava se na konkretnu aktivnost/doživljaje u destinaciji, primjerice, doživljaje vezane za atrakcije (Chen i Chen, 2010), sportske doživljaje (Che Wu i Ai, 2016), festivale, evente (Kirkup i Sutherland, 2017) i sl., dok vrlo malo istraživača uključuje tzv. zamišljanje svojih omiljenih načina ponašanja za vrijeme boravka i dozvoljava povezanost s unutarnjim razlozima za ponovni dolazak. 
Iskusni turisti nisu zadovoljni pasivnim razgledavanjem, već traže jedinstvene aktivnosti kojima će stvoriti nezaboravne doživljaje karakteristične za destinaciju u kojoj borave, primjerice, učenje izrade tradicionalnih predmeta, sudjelovanje u tradicionalnim igrama, komuniciranje s lokalnim stanovništvom o povijesti kraja i sl. Navedeno ne predstavlja novost, naime autor Fridgen (1984) je još prije više od tri desetljeća ustanovio da su ,turistički doživljaji stvoreni iz međuodnosa socijalne situacije, fizičke okoline i ljudskog ponašanja“. Međutim, s masovnošću turizma i sve jačim turističkim saturacijama, doživljaji turista se neopravdano marginaliziraju i pojednostavljuju kroz fizičko razgledavanje - promatranje okoline (destinacije). Valja naglasiti da se turistički doživljaji formiraju kroz proces interanalize svih interakcija (trenutaka istine) u destinaciji, a ishodi su subjektivni odgovori turista na cjelokupne doživljaje: (ne)zadovoljstvo, (ne)ispunjenje, lojalne namjere i sl. (Moon i Han, 2018). Pozitivnim subjektivnim odgovorima se nadalje kreiraju preferencije koje turist percipira kao preferirani stil odmora.

\section{LOJALNOST TURISTA}

Trendovi kao što su veći broj kraćih godišnjih odmora tijekom godine i posjećivanje više destinacija tijekom jednog odmora između ostalog upućuje i na potrebu daljnjih analiza o promjenama koje se održavaju na obrasce ponašanja turista (Almeida-Santana i Moreno-Gil, 2018). Realno je očekivati da će uslijed sve većeg izbora ponude, turisti biti sve manje zainteresirani za jednu destinaciju ili jedan brend. Pojavom multibrend lojalnosti turista (Felix, 2014), pojam lojalnosti temeljen na one-on-one loyalty principu polako gubi svoj identitet jer se lojalnost više ne promatra kroz interes jednog turističko-hotelskog poduzeća već se korist od lojalnosti turista dijeli na više pružatelja usluga. Društvena korist na makro ili mikro razini nema toliki značaj za pojedinačne pružatelje turističkih usluga, pa je stoga razumijevanje i istraživanje multibrend lojalnosti i sl. oblika lojalnosti u interesu nacionalnih, regionalnih i lokalnih destinacijskih organizacija. Lojalnost stilu odmora, za razliku od multibrend lojalnosti još je nedovoljno istražen pojam, a predstavlja tzv. lojalnost samom sebi, svojim dobro poznatim obrascima ponašanja za vrijeme boravka u jednoj ili više posjećenih destinacija. Ideja ove vrste lojalnosti zasniva se na pretpostavci da turist $\mathrm{s}$ vremenom razvija svoje preferencije u aktivnostima i doživljajima, koje s vremenom postaju stilovi ponašanja na odmoru.

S konceptualnog aspekta postoje dva osnovna pristupa istraživanja lojalnosti (San Martin, Collado i Rodriguez del Bosque, 2013): (1) bihevioralni pristup kojim se mjeri konkretan broj ponovljenih dolazaka turista (gostiju), te (2) stav turista, odnosno, namjera budućeg dolaska i namjera preporuke prijateljima i rodbini. Neki autori zagovaraju i na potrebu analize lojalnosti stavom kroz sekvencijalni proces koji je predložio Oliver (1999). Prema njegovu istraživanju lojalnost se iskazuje na četiri razine; na kognitivnoj, afektivnoj, konotacijskoj razini te se na kraju oblikuje u akcijsku lojalnost. To bi značilo da se lojalnost kod turista prvo stvara na temelju valorizacije ostvarenih koristi od ponovljene kupovine (kognitivna razina), nakon čega turist uzastopnim dolaskom stvara osjećaje povezanosti (afektivna razina), što se u konačnici reflektira kroz pozitivne namjere za budućom suradnjom (konotacijska lojalnost) i realiziranim ponovnim dolaskom (akcijska lojalnost). 
U ovom radu, lojalnost turista istražuje se kroz stav turista o budućim namjerama (konotacijska razina lojalnosti), na način da turist prvo zamisli svoj preferirani stil odmora (metoda scenarija), a onda odredi razinu slaganja s izjavama koje se tiču preporuka stila odmora svojim prijateljima i namjere ponovnog dolaska radi stila odmora.

\section{METODOLOGIJA I REZULTATI ISTRAŽIVANJA}

\subsection{Prikupljanje podataka i mjerne varijable}

Terensko istraživanje provedeno je na Opatijskoj Rivijeri, reprezentativnoj turističkoj destinaciji s najdužom turističkom tradicijom u Hrvatskoj (Grad Opatija, 2013). Ispitivanje su provele prethodno obučene osobe za ovaj tip istraživanja od lipnja do listopada 2019. godine. Od ukupno 350 distribuiranih upitnika, prikupljeno je 249 (stopa odgovora $71 \%$ ) koji su se kasnije koristili u analizi rada. Istraživanje je prvenstveno bilo usmjereno na otkrivanje motivacijskih čimbenika dolaska na Opatijsku Rivieru, te definiranje profila turista kroz motivacijske čimbenike i namjeru ponovnog dolaska radi svog stila odmora.

Motivacijski čimbenici mjereni su s 22 motivacijska pitanja (Yoon i Uysal, 2005) prilagođena području istraživanja. Mjerna ljestvica za lojalnost stilu odmora preuzeta je od Almeida-Santana i Moreno-Gil (2018) te Petrick (2002). Za oba seta pitanja korištena je Likertova ljestvica sa 7 stupnjeva, gdje 1 označava da nema utjecaja a 7 jaki utjecaj. U zadnjem dijelu anketnog upitnika postavljena su sociodemografska pitanja, te opća pitanja o posjetu.

\subsection{Eksploratorna faktorska analiza (EFA)}

U cilju sažimanja velikog broja motivacijskih čimbenika u manji broj logičkih faktora unutar kojih postoji značajna povezanost, prvi korak analize uključivao je eksploratornu faktorsku analizu (EFA). Nadalje, korištena je metoda glavnih komponenti (Principal Component Analysis - PCA) uz rotacijsku metodu Varimax with Kaiser Normalization radi determiniranja konceptualno logičnih faktora.

Prikladnost podataka određena je uz pomoć računskih testova: 1) Kaiser- Mayer-Olkinova mjera iznosi $0.714 ; 2)$ Bartlettov test je značajan $\left(X^{2}=941.460, \mathrm{df}=78\right.$, sg.= 0.000), ukazujući na jaku korelaciju između faktora i njegovih varijabli (tablica 1).

Iz tablice je vidljivo da su uz primjenu EFA analize izdvojena četiri faktora od kojih su tri push motivi (uzbuđenje, odmor i relaksacija te upoznavanje domaće kulture) i jedan pull motiv (outdoor aktivnosti). S ukupno četiri izlučena faktora, ukupni postotak varijance ukazuje da izlučeni faktori čine 68.957 \% informacija svih izvornih varijabli, što čini dovoljan postotak da bi se zaključilo o međusobnoj povezanosti varijabli (Hair, Black, Babin, i Anderson, 2014). Faktorska opterećenja su veća od 0.6 i manja od 0.912, što ukazuje na jaku korelaciju između izlučenih varijabli i njihovih pripadajućih faktora. Pouzdanost za sva četiri faktora određena je na temelju Cronbach Alpha koeficijenata. Vrijednosti se kreću između 0.657 i 0.856 , što ukazuje na pouzdane konstrukte. 
Tablica 1. Rezultati eksploratorne faktorske analize

\begin{tabular}{|l|c|c|c|c|}
\hline & Faktori & $\begin{array}{c}\text { Svojstvena } \\
\text { vrijednost }\end{array}$ & $\begin{array}{c}\% \\
\text { objašnjene } \\
\text { varijance }\end{array}$ & $\begin{array}{c}\text { Cronbach's } \\
\text { Alpha } \\
\text { koeficijent }\end{array}$ \\
\hline Faktor 1: Uzbuđenje & & 3.303 & 25.404 & 0.846 \\
\hline Potraga za avanturom i užitkom & 0.912 & & & \\
\hline Uzbudljive aktivnosti & 0.886 & & & \\
\hline Potraga za zabavom & 0.747 & & & \\
\hline Faktor 2: Odmor, relaksacija & & 2.247 & 17.283 & 0.726 \\
\hline Oslobađanje od stresa i tenzija & 0.841 & & & \\
\hline Odmaranje i opuštanje & 0.829 & & & \\
\hline Bijeg od svakodnevnice & 0.655 & & & \\
\hline $\begin{array}{l}\text { Uživanje i trošenje vremena s } \\
\text { rodbinom i prijateljima }\end{array}$ & 0.652 & & & \\
\hline $\begin{array}{l}\text { Faktor 3: Upoznavanje domaće } \\
\text { kulture }\end{array}$ & & 1.484 & 11.418 & \\
\hline Uživanje u lokalnim ručnim radovima & 0.814 & & & \\
\hline Upoznavanje kulture i životnih stilova. & 0.770 & & & \\
\hline $\begin{array}{l}\text { Prilika za vidjeti i upoznati ljude } \\
\text { različitih etničkih pripadnosti. }\end{array}$ & 0.708 & & & \\
\hline Faktor 4: Outdoor aktivnosti & & 1.405 & 10.805 & \\
\hline Vodeni sportovi & 0.785 & & & \\
\hline Rekreativne aktivnosti & 0.784 & & & \\
\hline Sportske igre & 0.691 & & & \\
\hline
\end{tabular}

Izvor: izrada autora

\subsection{Primjena klaster i regresijske analize}

Proces segmentiranja omogućava marketinškim kompanijama da strateški definiraju svoje ciljne segmente, usmjeravajući time svoje resurse na one segmente koji su se izdvojili kao najveći potencijal za prodaju proizvoda i usluga (McDonald i Dunbar, 2012). U cilju identificiranja ključnih klastera, u radu je primijenjena Two-step klaster analiza. Ova klastering metoda procijenjena je kao najbolja za podatke koji će se analizirati u ovoj studiji, uvažajući da se uz pomoć Two-step kluster analize može simultano analizirati psihografske, demografske i bihevioralne podatke (Rundle-Thiele i dr., 2015). Nadalje, Two-step klaster analiza pokazala se kao vjerodostojna metoda s jakom eksploratornom sposobnošću (Aho i dr., 2014).

Faktori koji su se izlučili u prethodnom koraku, koristili su se kao sastavne varijable u identificiranju klastera (turista) sa sličnim motivima (tablica 2). Kao mjera za udaljenost (distance measure) korištena je Log- Likelyhood, te klaster kriterij AIC (Aho i dr., 2014). Silhouette mjera kohezije i separacije je 0,6, što ukazuje na dobru koheziju i separaciju klastera. Rezultati ANOVA testa potvrđuju statistički značajne razlike između utvrđenih klastera baziranih na motivacijskim čimbenicima $(\mathrm{p}<0.001)$. 
Tablica 2. Klasteri prema motivacijskim faktorima

\begin{tabular}{|c|c|c|c|c|c|c|c|}
\hline \multicolumn{2}{|l|}{ Faktori } & $\mathrm{N}$ & A.S. & $\begin{array}{c}\text { Std. } \\
\text { devijacija }\end{array}$ & $\begin{array}{c}\text { Std. Error } \\
\text { Mean }\end{array}$ & $\mathrm{F}$ & sig. \\
\hline \multirow{2}{*}{ Uzbuđenje } & 1 & 74 & 3.41 & 1.53 & 0.178 & \multirow{2}{*}{87.704} & \multirow{2}{*}{0.000} \\
\hline & 2 & 175 & 5.37 & 1.50 & 0.113 & & \\
\hline \multirow{2}{*}{ Odmor i relaksacija } & 1 & 74 & 4.55 & 1.63 & 0.189 & \multirow{2}{*}{88.990} & \multirow{2}{*}{0.000} \\
\hline & 2 & 175 & 6.06 & 0.88 & 0.066 & & \\
\hline \multirow{2}{*}{$\begin{array}{l}\text { Upoznavanje domaće } \\
\text { kulture }\end{array}$} & 1 & 74 & 3.37 & 1.35 & 0.157 & \multirow{2}{*}{91,113} & \multirow{2}{*}{0.000} \\
\hline & 2 & 175 & 5.08 & 1.27 & 0.095 & & \\
\hline \multirow{2}{*}{ Outdoor aktivnosti } & 1 & 74 & 1.53 & 0.88 & 0.102 & \multirow{2}{*}{36.748} & \multirow{2}{*}{0.000} \\
\hline & 2 & 175 & 2.61 & 1.42 & 0.107 & & \\
\hline
\end{tabular}

Izvor: izrada autora

U prvi klaster spadaju turisti koji su u pravilu slabo motivirani uzbuđenjem, vanjskim aktivnostima i upoznavanjem domaće kulture. Drugim riječima, to su turisti koje ne zanimaju aktivnosti već su se prvenstveno došli odmoriti i relaksirati, stoga se promatraju kao pasivni turisti. Za razliku od prvog, u drugom klasteru nalaze se turisti koji su snažno motivirani za avanturizam, upoznavanje kulture i relaksaciju, odnosno odmor. Stoga će se navedena dva klastera (tablica 3) imenovati kao 1) nedruštveni i pasivni te 2) društveni i aktivni.

Tablica 3. Izdvojeni klasteri

\begin{tabular}{|l|l|r|}
\hline Klaster 1 & $\begin{array}{l}\text { Turisti željni odmora i socijalne distance (nedruštveni i } \\
\text { pasivni) }\end{array}$ & $156(62,7 \%)$ \\
\hline Klaster 2 & $\begin{array}{l}\text { Turisti željni odmora, uzbuđenja i socijalne bliskosti } \\
\text { (društveni i aktivni) }\end{array}$ & $93(37,3 \%)$ \\
\hline
\end{tabular}

Izvor: izrada autora

U cilju određivanja profila podijeljenih prema definiranim klasterima korištene su tzv. cross tablice (tablica 4). 
Tablica 4. Profil odmorišnih turista koji su boravili na Opatijskoj rivijeri

\begin{tabular}{|c|c|c|c|c|}
\hline Profil & Klaster 1 & Klaster 2 & Ukupno & Hi kvadrat test \\
\hline \multicolumn{5}{|l|}{ Spol } \\
\hline Muški & 31 & 69 & 100 & \multirow{2}{*}{$\begin{array}{c}\text { chi }^{2}=3.078 \\
\mathrm{p}=0.380\end{array}$} \\
\hline Ženski & 42 & 107 & 149 & \\
\hline \multicolumn{5}{|l|}{ Godine } \\
\hline $16-22$ & 3 & 23 & 26 & \multirow{5}{*}{$\begin{aligned} \mathrm{chi}^{2} & =12.632 \\
\mathrm{p} & <0.05\end{aligned}$} \\
\hline $23-36$ & 11 & 46 & 57 & \\
\hline $37-52$ & 16 & 33 & 49 & \\
\hline $53-72$ & 31 & 59 & 90 & \\
\hline $73-100$ & 13 & 14 & 27 & \\
\hline \multicolumn{5}{|l|}{ Zemlja dolaska } \\
\hline Domaći turisti & 3 & 25 & 28 & \multirow{4}{*}{$\begin{array}{c}\operatorname{chi}^{2}=5.594 \\
\mathrm{p}=0.133\end{array}$} \\
\hline Europski turisti $<500 \mathrm{~km}$ & 29 & 65 & 94 & \\
\hline Europski turisti $>500 \mathrm{~km}$ & 29 & 59 & 88 & \\
\hline Turisti s drugih kontinenata & 12 & 27 & 39 & \\
\hline \multicolumn{5}{|l|}{ Zaposlenost } \\
\hline Zaposlen & 28 & 80 & 108 & \multirow{4}{*}{$\begin{array}{c}\mathrm{chi}^{2}=10.338 \\
\mathrm{p}<0.05\end{array}$} \\
\hline Nezaposlen & 6 & 9 & 15 & \\
\hline U mirovini & 35 & 53 & 88 & \\
\hline Student & 5 & 32 & 37 & \\
\hline \multicolumn{5}{|l|}{ Razina obrazovanja } \\
\hline Osnovna škola & 0 & 5 & 5 & \multirow{3}{*}{$\begin{array}{c}\text { chi }^{2}=6.494 \\
\mathrm{p}=0.09\end{array}$} \\
\hline Srednja škola & 30 & 60 & 90 & \\
\hline Fakultet & 39 & 115 & 154 & \\
\hline \multicolumn{5}{|l|}{ Dužina boravka } \\
\hline 1 - 2 noćenja & 10 & 26 & 36 & \multirow{4}{*}{$\begin{array}{c}\operatorname{chi}^{2}=12.603 \\
\mathrm{p}=0.858\end{array}$} \\
\hline 3 - 4 noćenja & 15 & 33 & 48 & \\
\hline 5 - 7 noćenja & 34 & 71 & 105 & \\
\hline 8 i više & 25 & 35 & 60 & \\
\hline \multicolumn{5}{|l|}{ Tip smještaja } \\
\hline $\begin{array}{l}\text { Hotel i smještaj sličan } \\
\text { hotelskom }\end{array}$ & 59 & 111 & 170 & \multirow{4}{*}{$\begin{array}{c}\text { chi }^{2}=7.259 \\
p=0.202\end{array}$} \\
\hline Hostel & 5 & 8 & 13 & \\
\hline Privatni smještaj & 12 & 40 & 52 & \\
\hline Ostalo & 2 & 12 & 14 & \\
\hline
\end{tabular}

Izvor: izrada autora 
Rezultati hi kvadrat testa ukazuju da su klasteri značajno različiti kod dvije sociodemografske karakteristike ispitanika: zaposlenosti i godina ispitanika. U cilju utvrđivanja statistički značajnih razlika između definiranih klastera u odnosu na namjere ponovnog dolaska i namjere preporuke, primijenjen je T-test (tablica 5). Faktor „Namjera ponovnog dolaska“ sastoji se od tri varijable (1) „Ako ponovno posjetim Hrvatsku, odabrat ću isti stil odmora“, (2) „Ovaj stil odmora bit će moj prvi izbor među ostalim stilovima odmora u Hrvatskoj“, (3) „Zainteresiran sam za isti stil odmora u Hrvatskoj unutar iduće tri godine“, a „Namjera preporuke“ od dvije varijable (1) „Preporučit ću ovaj stil odmora svojim prijateljima“, (2) „Kada budem govorio o svom stilu odmora, govorit ću pozitivno“. Prije primjene T-testa, za oba faktora i njihove pripadajuće varijable izračunate su prosječne vrijednosti, varijable su spojene pomoću opcije spajanja i izračuna srednjih vrijednosti u SPSS-u.

Tablica 5. Rezultati T-testa

\begin{tabular}{|l|c|c|c|c|c|}
\hline Testne Varijable & $\begin{array}{c}\text { Klaster 1 } \\
\text { (A.S) }\end{array}$ & $\begin{array}{c}\text { Klaster 2 } \\
\text { (A.S.) }\end{array}$ & $\begin{array}{c}\text { F } \\
\text { vrijednost }\end{array}$ & T-test & $\begin{array}{c}\text { sig. } \\
\text { (2-tailed) }\end{array}$ \\
\hline Namjera ponovnog dolaska & 5,0411 & 5,5867 & 14.050 & $-2,623$ & 0.009 \\
\hline Namjera preporuke & 5.9257 & 6.2457 & 14.273 & $-1,826$ & 0.05 \\
\hline
\end{tabular}

Izvor: izrada autora

Podaci ukazuju na statistički značajnu razliku između klastera pri namjeri ponovnog dolaska i namjeri preporuke stila odmora. Negativne vrijednosti T-testa ukazuju da turisti koji su došli radi odmora i aktivnosti, te su željni društvenog kontakta (klaster 2) imaju statistički značajniju namjeru ponovnog dolaska i namjeru preporuke svog stila odmora u odnosu na pasivne turiste koji nisu socijalno aktivni (klaster 1) .

U nastavku je provedena OLS regresijska analiza kako bi se utvrdila uzročno posljedična povezanost između izlučenih motivacijskih čimbenika i lojalnosti stilu odmora (tablica 6).

Tablica 6. Utjecaj motivacijskih čimbenika na namjeru ponovnog dolaska radi stila odmora

\begin{tabular}{|c|c|c|c|c|c|}
\hline \multirow{2}{*}{ Varijable } & \multirow{2}{*}{ B } & \multirow{2}{*}{$\begin{array}{c}\text { Std. } \\
\text { greška }\end{array}$} & \multirow{2}{*}{ sig. } & \multicolumn{2}{|c|}{ Pokazatelji kolinearnosti } \\
\hline & & & & Tolerancija & VIF \\
\hline F1 Uzbuđenje & 0.110 & 0.058 & 0.057 & 0.815 & 1.227 \\
\hline F2 Odmor i relaksacija & 0.352 & 0.068 & 0.000 & 0.983 & 1.017 \\
\hline F3Upoznavanje domaće kulture & -0.053 & 0.064 & 0.410 & 0.888 & 1.127 \\
\hline F4 Outdoor aktivnosti & -0.017 & 0.071 & 0.811 & 0.877 & 1.140 \\
\hline
\end{tabular}

Izvor: izrada autora

$\mathrm{R}^{2}=0.344, \mathrm{~F}(8.155, \mathrm{df}=4), \mathrm{p}<0.01, \beta-$ nestandardizirane vrijednosti - jednaka mjerna ljestvica

Rezultati regresijske analize ukazuju da je od četiri motivacijska čimbenika samo jedan značajno povezan s namjerom ponovnog dolaska. Naime, samo kod turista koji su došli na Opatijsku rivijeru radi primarnog motiva „Odmor i relaksacija“ postoji značajna 
uzročno-posljedična povezanost s namjerom ponovnog dolaska radi stila odmora. U nastavku slijede rezultati OLS regresije za iste motivacijske čimbenike i njihov utjecaj na namjeru preporuke stila odmora.

Tablica 7. Utjecaj motivacijskih čimbenika na namjeru preporuke stila odmora

\begin{tabular}{|c|c|c|c|c|c|}
\hline \multirow{2}{*}{ Varijable } & \multirow{2}{*}{ B } & \multirow{2}{*}{$\begin{array}{l}\text { Std. } \\
\text { greška }\end{array}$} & \multirow{2}{*}{ sig. } & \multicolumn{2}{|c|}{ Pokazatelji kolinearnosti } \\
\hline & & & & Tolerancija & VIF \\
\hline F1 Uzbuđenje & 0.070 & 0.049 & 0.152 & 0.814 & 1.228 \\
\hline F2 Odmor i relaksacija & 0.251 & 0.058 & 0.000 & 0.985 & 1.015 \\
\hline F3Upoznavanje domaće kulture & 0.030 & 0.054 & 0.577 & 0.889 & 1.125 \\
\hline F4 Outdoor aktivnosti & 0.025 & 0.061 & 0.685 & 0.879 & 1.138 \\
\hline
\end{tabular}

$\mathrm{R}^{2}=0.309, \mathrm{~F}(6.388, \mathrm{df}=4), \mathrm{p}<0.01, \beta$ - nestandardizirane vrijednosti - jednaka mjerna ljestvica

Slični rezultati razvidni su i u tablici br. 7., prema kojoj je vidljivo da „Odmor i relaksacija“" predstavlja jedini statistički značajan prediktor namjere preporuke stila odmora.

Nadalje, može se zaključiti da push motivi u odnosu na pull motive značajnije utječu na namjeru ponovnog dolaska i preporuke. Drugim riječima, turisti koji su ispunili svoje unutarnje motive, u ovom slučaju motive koji se odnose na odmor i relaksaciju pokazuju značajno veću namjeru ponovnog dolaska radi stila odmora i preporuke svojim prijateljima u odnosu na pull motive.

\section{RASPRAVA I ZAKLJUČAK}

Primarni ciljevi ovog rada su izlučivanje ključnih motivacijskih čimbenika kod turista koji su boravili na Opatijskoj Rivijeri, te izrada profila turista i povezivanje s bihevioralnim namjerama usmjerenim na stil odmora. Od 22 motivacijska pitanja izdvojila su se četiri faktora, od kojih su tri push motiva (uzbuđenje, odmor i relaksacija te upoznavanje domaće kulture) te jedan pull motiv (outdoor aktivnosti). Rezultati istraživanja ukazuju na dvije temeljne skupine turista prema izdvojenim push i pull motivima za dolazak na Opatijsku rivijeru, od kojih „odmor i relaksacija“ najznačajnije utječu na namjeru ponovnog dolaska u Hrvatsku radi stila odmora i preporuke svog stila odmora. Nadalje, rezultati T-testa ukazuju da postoji statistički značajna razlika između profila turista u bihevioralnim namjerama vezanim za stil odmora. Može se zaključiti da turisti koji su došli radi odmora, ali i uzbuđenja i društvenog kontakta imaju bolje ispunjena očekivanja od turista, koji nisu zainteresirani za društveni kontakt. Doživljaji koji se ostvaruju putem socijalnih kontakata i uzbuđenja upotpunjuju turiste i oni su u konačnici turisti koji su se u kontekstu bihevioralnih namjera pokazali lojalnijima.

Prijašnja istraživanja (Dimitrovski i Todorović, 2015) ističu grupiranje motiva dolaska uz pomoć klaster analize kao koristan alat pri segmentiranju turista. Skupine koje su se izdvojile kao značajne i pouzdane mogu poslužiti kao ciljni segmenti prema u koje je potrebno uložiti dodatne napore po pitanju promocijskih kampanja (Rundle-Thiele, Kubacki, Tkaczynski, i Parkinson, 2015). Na temelju ovog članka destinacijskim menadžerima omo- 
gućeno je bolje razumijevanje motiva dolaska i razine ispunjenja njihovih očekivanja, koji se odražavaju u povratnoj vezi kroz namjeru ponovnog dolaska i namjeru preporuke. Kao dodatne implikacije, može se izdvojiti korist od usmjeravanja destinacijskih menadžera na predloženi okvir segmenata. Imajući na umu njihove motive, lakše će se i bolje ustanoviti potrebe segmenata. S obzirom na to da je istraživanje pokazalo da turisti s preferiranim stilom odmora dolaze prvenstveno radi društvenih sadržaja, ovaj segment zahtjeva poseban angažman po pitanju dodatnih aktivnosti, posebice adrenalinskih aktivnosti gdje se mogu družiti i upoznavati domaću kulturu.

Turisti lojalni svom stilu odmora su turisti koji su iskusni, a nezaboravni doživljaji se za njih ostvaruju kroz nematerijalne aspekte destinacije, koji ih ispunjavaju i vežu na način da ponovno žele osjetiti preferirani i specifični način trošenja slobodnog vremena. S obzirom na to da je razlog povratka neovisan o destinaciji (Opatijska rivijera), već vezan za mogućnosti ispunjenja njihovih unutarnjih potreba, potrebno je uložiti napore u povezivanje destinacija kroz tematske aktivnosti, gdje će ti turisti dolaziti i ispunjavati svoje potrebe. Kao indirektni efekt, korist se od takvih turista odmiče od lokalne ka regionalnoj i nacionalnoj. Pretpostavka koja logički proizlazi iz rezultata istraživanja je da se ti turisti mogu vezati za Hrvatsku kao destinaciju „,na višoj razini“, ako se tim turistima omogući ispunjavanje njihovih unutarnjih potreba kroz dobro povezanu mrežu aktivnosti među destinacijama.

Prijašnja istraživanja pokazuju da turisti koji dolaze radi ozbiljnih sportova poput golfa, planinarenja i sl. imaju sličan oblik izražavanja lojalnosti (Backman i Crompton, 1991), stoga ovaj istraživački rad nadopunjuje istraživački jaz u dijelu istraživanja turista koji dolaze na odmor, a kod kojih postoji jasna slika o vlastitom stilu odmora.

S obzirom na to da je fokus istraživanja prijašnjih autora na temu lojalnosti turista u većini slučajeva usmjeren ka materijalnom, može se zaključiti da je to prije svega rezultat nedovoljnog uključivanja percepcije turista o aktivnostima i doživljajima, polazeći od pretpostavke da je turist više vezan za destinaciju ili smještaj gdje boravi, u odnosu na aktivnosti za vrijeme boravka u destinaciji na mikro ili makro razini. Uvažavajući trendove, očekuje se da će se u budućnosti intenzivirati istraživanja koja uključuju unutarnje načine povezanosti s destinacijama, aktivnostima i sl. Stoga se kao logičan nastavak ovog istraživačkog rada budućim istraživačima lojalnosti turista predlaže daljnje ispitivanje potreba turista lojalnih stilu odmora, u cilju identificiranja segmenata kroz njihove potrebe usmjerene na aktivnosti.

\section{POPIS LITERATURE}

Almeida-Santana, A., Moreno-Gil, S. (2018). Understanding tourism loyalty: Horizontal vs. destination loyalty. Tourism Management, 65, 245-255. doi:10.1016/j.tourman.2017.10.011

Anton, C., Camarero, C., Laguna-Garcia, M. (2014). Towards a new approach of destination loyalty drivers: satisfaction, visit intensity and tourist motivations. Current Issues in Tourism, 1-25.

Backman, S., Crompton, J. (1991). The usefulness of selected variables for predicting activity loyalty. Leisure Sciences, 13(7-23), 205-220. 
Chang, L., Backman, K., Huang, Y. (2014). Creative tourism: a preliminary examination of creative tourists' motivation, experience, perceived value and revisit intention. International Journal of Culture, Tourism and Hospitality Research, 8(4), 401-419.

Che Wu, H., Ai, C. (2016). Synthesizing the effects of experiential quality, excitement, equity, experiential satisfaction on experiential loyalty for the golf industry:The case of Hainan Island. journal of Hospitality and Tourism Management, 29, 41-59.

Chen, C., Chen, F. (2010). Experience quality, perceived value, satisfaction, and behavioral intentions for heritage tourists. Tourism Management, 31(1), 29-35.

Dimitrovski, D., Todorović, A. (2015). Clustering wellness tourists in spa environment. Tourism Management Perspectives, 16, 259-265.

Dolnicar, S. (2004). Beyond "Commensense segmentation" - A systematics of segmentation approaches in tourism. Journal of Travel Research, 42(3), 244-250.

Felix, R. (2014). Multi-brand loyalty: when one brand is not enough. Qualitative Market Research: An International Journal, 17(4), 464-480.

Fridgen, J. D. (1984). Environmental psychology and tourism. Annals of Tourism Research, 11(1), 19-39.

Hair, J., Black, W., Babin, B., Anderson, R. (2014). Multivariate Data Analysis. London: Pearson Education Limited.

Harril, R., Potts, T. (2002). Social Psychological Theories of Tourist Motivation: Exploration, Debate, and Transition. Tourism Analysis, 7(2), 105-114.

Kirkup, N., Sutherland, M. (2017). Exploring the relationships between motivation, attachment and loyalty within sport event tourism. Current Issues in Tourism, 20(1), 7-14.

Laškarin Ažić, M., Suštar, N. (2021). Loyalty to holiday style: motivational determinants. Tourism Review, Ahead-of-print (Aead-of-print). doi:https://doi.org/10.1108/TR-062020-0254

McDonald, M., Dunbar, I. (2012). Market Segmentation: How to Do it and How to Profit from It, . Chichester: John Wiley Sons.

McKercher, B., Denizci-Guillet, B., Ng, E. (2012). Rethinking loyalty. Annals of Tourism Research, 39, 708-734. doi:10.1016/j.annals.2011.08.005

Moon, H., Han, H. (2018). Tourist experience quality and loyalty to an island destination: the moderating impact of destination image. Journal of Travel Tourism Marketing, 36(1), 43-59.

Oliver, R. (1997). Satisfaction: A Behavioral Perspective on the Consumer. New York: McGraw-Hill.

Opatija, G. (2013, siječanj). Retrieved from https://www.opatija.hr/hr/vijesti/novosti/opatijska-karnevalska-tradicija-u-nesvakidasnjem-sjaju,838.html

Rundle-Thiele, S., Kubacki, K., Tkaczynski, A., Parkinson, J. (2015). Using two-step cluster analysis to identify homogeneous physical activity groups. Marketing Intelligence \& Planning, 522-537.

San Martin, H., Collado, J., Rodriguez del Bosque, I. (2013). An exploration of the effects of past experience and tourist involvement on destination loyalty formation. Current Issues in Tourism, 16(4), 327-342. 
Suhartanto, D., Brien, A., Primiana, I., Wibisono, N., Nyoman, T. (2019). Tourist loyalty in creative tourism: the role of experience quality, value, satisfaction, and motivation. Current Issues in Tourism, 1-13.

Wong, I., Tang, S. (2016). Linking Travel Motivation and Loyalty in Sporting Events: The Mediating Roles of Event Involvement and Experience, and the Moderating Role of Spectator Type. Journal of Travel \& Tourism Marketing, 33(1), 63-84.

Woo, B., Trail, G. T., Kwon, H. H., Anderson, D. F. (2009). Testing models of motives and points of attachment. Sport Marketing Quarterly, 18, 38-53.

Yi, X., Fu, X., Jin, W., Okumus, F. (2018). Constructing a model of exhibition attachment: Motivation, attachment, and loyalty. Tourism Management, 65, 224-236.

Yoon, Y., U. M. (2005). An examination of the effects of motivation and satisfaction on destination loyalty: a structural model. Tourism Management, 26, 45-56.

www.theguardian.com (preuzeto 8. veljače 2021.)

www.gradopatija.com (preuzeto 8. veljače 2021.) 